DOI: $\underline{\text { https://doi.org/10.34069/AI/2021.42.06.24 }}$

How to Cite:

Borinshtein, Y., Stovpets, O., Kukshinova, O., Kisse, A., \& Kucherenko, N. (2021). Phenomena of freedom and justice in the interpretations of T. Hobbes and J. Locke. Amazonia Investiga, 10(42), 255-263. https://doi.org/10.34069/AI/2021.42.06.24

\title{
Phenomena of freedom and justice in the interpretations of T. Hobbes and J. Locke
}

\author{
Fenómenos de libertad y justicia en las interpretaciones de T. Hobbes y J. Locke
}

Received: May 11, 2021

Accepted: June 28, 2021

\begin{abstract}
This study gives a possible representation of $\mathrm{T}$. Hobbes and J. Locke's visions of the essence of 'freedom' and 'justice' phenomena. The philosophic-historical analysis performed in the article made it possible to reveal the fundamental ideological conflict between statism and liberalism, between the utilitarian, entirely pragmatic understanding the nature of the social contract (in Hobbes's political philosophy), and moral-ethical accents on the essential foundations of a state-organized society (in Locke's political thoughts). Hobbes generally ignores the moral and ethical preconditions inherent to human nature, reducing the social contract ontology to purely utilitarian aspects. The freedom of the individual loses its absolute character, as each member of this socio-political community gives up a part of his freedom in favor of 'Leviathan' (i.e. the sovereign, the state). Beginning from this moment it is fair for each individual to comply with the terms of that universally binding social contract, and its violation by someone within the community
\end{abstract}

\author{
Written by: \\ Yevgen Borinshtein ${ }^{107}$ \\ https://orcid.org/0000-0002-0323-4457 \\ Oleksandr Stovpets ${ }^{108}$ \\ https://orcid.org/0000-0001-8001-4223 \\ Olga Kukshinova ${ }^{109}$ \\ https://orcid.org/0000-0003-0470-6863 \\ Anton Kisse ${ }^{110}$ \\ https://orcid.org/0000-0002-7875-4617 \\ Natalia Kucherenko ${ }^{111}$ \\ https://orcid.org/0000-0002-5130-8238
}

\section{Resumen}

El artículo intenta representar la visión de T. Hobbes y J. Locke sobre la esencia de los fenómenos de libertad y justicia. El análisis histórico y filosófico realizado permitió revelar el conflicto ideológico fundamental entre el estatismo y el liberalismo, entre la comprensión utilitarista y puramente pragmática de la naturaleza del contrato social (en la filosofía política de Hobbes) y los acentos morales y éticos sobre los fundamentos esenciales del sociedad (en política y filosófica visiónes de Locke). Hobbes generalmente ignora las precondiciones morales y éticas inherentes a la naturaleza humana, reduciendo la ontología del contrato social a aspectos puramente utilitarios. La libertad del individuo pierde su carácter absoluto, pues cada miembro de esta comunidad sociopolítica cede parte de su libertad a favor del Leviatán, se compromete a limitar su libertad a cambio de bienestar y relativa seguridad. A partir de este momento, se considera justo que cada individuo cumpla con los términos de un contrato social obligatorio, y su violación por alguien

\footnotetext{
107 Doctor Hab. in Philosophical Sciences, Professor, head of the department of Philosophy, Sociology and Management of sociocultural activities, The state institution "South Ukrainian National Pedagogical University named after K.D. Ushynsky", Ukraine. ${ }^{108}$ Doctor Hab. in Philosophical Sciences, Professor of the Criminal and Administrative Law department, \& Philosophy department, Odessa National Maritime University, Ukraine.

${ }^{109} \mathrm{PhD}$ in Legal Sciences, Associate professor, head of the Criminal and Administrative Law department, Odessa National Maritime University, Ukraine.

${ }^{110}$ Doctor Hab. in Political Science, professor of the department of Philosophy, Sociology and Management of sociocultural activities, The state institution "South Ukrainian National Pedagogical University named after K.D. Ushynsky", the People's deputy of the Verkhovna Rada of Ukraine.

${ }^{111} \mathrm{PhD}$ scholar, teacher, Philosophy dept., Odessa National Maritime University, Ukraine.
} 
deemed to be unjust. On the contrary, Locke forms an idea of the ethical basis of the human community. Locke's political anthropology is based on the close relationship between the principle of justice and the imperatives of reason. The latter ones approach the universal ethical and legal requirements to ensure equal opportunities in the implementation and protection of freedoms and interests of the individual living in society. Under such conditions, justice means that a person acquires the maximum opportunities to fulfill his own freedoms (in all its diversity), without violating the freedoms of others.

Keywords: freedom, justice, social contract, state, Hobbes, Locke.

\section{Introduction}

Freedom and Justice are universal values that do not lose their relevance in any cultural and historical epoch. Philosophical attention to them is dictated by human nature itself. The constant interest in these general humanitarian phenomena is fueled by specific historical realities, and today it is becoming particularly acute. The polysemantic categories of "freedom" and "justice" provide space for multivariate interpretations of their content, and such interpretations are not always carried out in favor of a man, individual, personality.

The purpose of this study is mainly to perform a retrospective analysis of the phenomena of Freedom and Justice, which obtained a deep conceptualization in the days of early modernity philosophy. Of course, almost every influential philosopher of this era did not ignore these universal values. However, considering the format of this study, we will limit ourselves to a historical and philosophical analysis of the relevant ideas of two thinkers who made a huge contribution to the development of philosophical and political discourse of the Modern Age: they are Thomas Hobbes and John Locke. Two main objects of this research are "Freedom" and "Justice" in those senses what were originally implicated in Hobbes' and Locke's doctrines, and their meaning for nowadays.

The importance of research of such a multilateral notions as Freedom and Justice, as we think, is connected with different views on the role of the State and Civil society in contemporary political process, and a long-standing controversy between statism and liberalism. We believe that better understanding of the original content of these notions would contribute into dentro de la comunidad considerado injusto. Locke, por otro lado, se forma una idea de la base ética y legal de la comunidad humana. La antropología política de Locke se basa en la estrecha relación entre los principios de justicia y los imperativos de la razón. Estos últimos abordan los requisitos éticos y legales universales para garantizar la igualdad de oportunidades en la implementación y protección de las libertades e intereses del individuo que vive en sociedad. La justicia significa que una persona adquiere las máximas oportunidades para ejercer su propia libertad, sin violar las libertades de los demás.

Palabras clave: libertad, justicia, acuerdo social, estado, Hobbes, Locke.

modern social-philosophic, legal and political discussions on how they should be interpreted and unfold in modern social reality.

That is the main reason why we decided to focus our attention on the contradictory aspects in "Freedom" and "Justice" phenomena's understanding by Hobbes and Locke. We hope, this attempt at a historical and philosophical representation of T. Hobbes's and J. Locke's visions will help to comprehend how these two concepts have changed since the days when the mentioned classical liberal thinkers lived.

The current knowledge of the topic is not restricted only with the original works, as Hobbesian "Leviathan: Or the Matter, Forme, and Power of a Common-Wealth Ecclesiasticall and Civill" (Hobbes, reprint 2010) and other political works (Hobbes, 1991), or with Locke's "Essays on the Law of Nature" (Locke, reprint 2002), "Two Treatises of Government" (Locke, reprint 2003). There are some contemporary works aimed at the comprehension of Hobbes' ideas, for instance, the work "The Limits of Hobbesian Contractarianism" (Kraus, 1993). Locke's intellectual legacy was the matter of some later influential researches, among which was P. Laslett's "Introduction to Locke's Two Treatises of Government" (Laslett, 2003).

\section{Theoretical and methodological framework}

Methodology of the research is based on formal logical methods of analysis and synthesis, on a comparative method, and an axiological approach. Methodologically important, to clarify the common and different in views by T. Hobbes and J. Locke on the phenomena of freedom, 


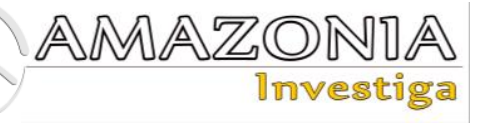

justice, and other related notions, we consider those studies, which cover the following issues: the historical context of writing Locke's "Treatises of Government" (Laslett, 1956); Locke's justification of private property (Day, 1966); the question of the transition from the "state of nature" to political society (Hardin, 1993); dialectics of the natural and the artificial in social space (Skinner, 1999); on some axioms in the realm of individual rights (Miller, 2011); issues of moral obligations to the law, as well as the natural right for freedom of association (Davis, 2012); the question of the so-called distributive justice (Olsthoorn, 2013); reconsidering Locke's 'jus naturale' tradition (Seagrave, 2015); the concept of materialism and its consequences for morality (Springborg, 2016); the question on the relationship between justice and fairness (Hoye, 2019); issues of stability and diversity in the discourse of social conventionalism (Moehler, 2019); the problem of morality and its implementation in life practice (Connolly, 2019); understanding the consequences of violating the political agreement (Fleming, 2020); current discussions on the nature of the sovereign (Apeldoorn, 2020); the problem of so-called "minimal state" in the discussions between liberalism and libertarianism (Bruner, 2020).

The presentation of main ideas, results and discussion

The appeal to the legacy of Thomas Hobbes and John Locke is due not only to the historical and philosophical interest in these figures of modern European philosophy. It is due to the great influence that Hobbes' and Locke's ideas expand on the development of modern social philosophy (and liberal theory, and the theory of justice - as the cornerstones of political philosophy). Both thinkers operated with the categories of "freedom", "justice", "property", "enforcement", "equality", "social agreement". For each of them, the question of the "state of nature" was a main starting point in all subsequent reflections on freedom and justice. However, each philosopher filled all these concepts with different meanings.

Quite common is the notion in which Locke is associated with the development of the ideology of liberalism, and Hobbes, on the contrary, is presented as a harbinger of totalitarianism, who saw in the idea of absolute power the only real way to prevent mutual enmity between people by reconciling their interests. Therefore, from his earliest works, Locke distanced himself from Hobbes, criticizing the latter for the excessive utilitarianism and materialism that are actually read in Hobbes's political philosophy. Locke, on the other hand, believed that a purely conventional basis for ethical norms is alien, and that ethical substance itself is the basis of justice and freedom.

Man, according to T. Hobbes, is both a physical and a spiritual being. Its spirituality is expressed in the fact that man is the creator of culture. The most important social value created by man is the state. Hobbes considered the doctrine of the state to be the main task of his philosophy, based on the concept of human nature. According to Hobbes, human nature is purely selfish (Hobbes, 1991, B. II). Hobbes' ethics stems from the "sensual nature" of a human. Hobbes considered the "natural law" as a basis of morality, meaning by that human desire for self-preservation and satisfaction of needs.

Hobbes's doctrine of society and the state is a kind of result of all his philosophical research. Hobbes's political theory, detailed in his major work "Leviathan" (Hobbes, 2010), is based on the dialectic of collective, social-state and individual-personal principles. Hobbes believed that people are equal by nature, because nature endows all people with similar physical and spiritual gifts. From the potential equality of abilities arises the equality of hopes for achieving goals. That is why, if two people want the same thing, which however they cannot own together, then they become irreconcilable rivals, and because of mutual distrust a war arises (Hobbes, 1991, B. II: 93-94).

It is possible to avoid a "war of all against all" by using the treaty. Contract theories, even before Hobbes, took place in ancient Chinese and ancient Greek philosophy. Plato points out that Glaucon was a supporter of contract theory (Platóno, 1962). However, these theories, significantly preceding the philosophy of the Modern Age, have not yet been so consistently developed. In addition, the very problem of justice (in the context of contract theory) is filled by Hobbes with new meaning, presenting new facets that allow us to understand better the essence of justice at the contemporary era.

Hobbes develops the contractual theory of the origin of the state and the concept of justice based on the selfish essence of man. He is convinced that where there is no strong government capable of keeping everyone in control, people for some reason are not able to coexist peacefully and safely in the format of society. Three main causes of war are rooted in human nature itself: rivalry, mistrust, and ambition. Hobbes's interpretation 
of war takes on such a meaning that "... war is not only a battle or a military action, but also a period of time during which the will to fight, or acting by force is clearly affected" (Hobbes, 1991, B. II: 95).

Speaking of Hobbes' concept of justice, it seems important to us to single out his idea that in the "natural state" (i.e. in a state of "war of all against each other") the concepts of legal and non-legal, just and unjust, simply do not exist yet. Where there is no supreme power, there is obviously no universally binding law. From this vision Hobbes concludes that the absence of law also does not give grounds to speak of "injustice", as no one violates any social law (just because of the absence of such). Proprietary discourse is added to this issue: "The mentioned condition is also characterized by the lack of property, of possession. Everyone considers as his own only those things, which the one is capable to obtain, to take, but only as long as he is able to hold it" (Hobbes, 1991, B. II: 96-97). In other words, the very concept of justice (which could be converted into 'legal equity' within a state), as well as property, arise, according to Hobbes, only in the space of a politically organized society.

In "Leviathan", Hobbes argues that the natural inequality between people is not so great as to give anyone a clear advantage; and therefore all are forced to live in constant fear of violence or loss. This state of affairs is called "bellum omnium contra omnes". In this state (the pure state of nature, or "the natural condition of mankind") everyone has the natural right to do whatever he deems necessary to save his own life, however everyone's life is "... lonely, poor, ugly, cruel, and short" (Hobbes, 2010, Ch. XIIIXIV).

Hobbes builds his contractual theory on the basis of natural law (natural right, or 'jus naturale') and natural laws (laws of nature, or 'leges naturales'), which derive from this law. The basic (first) natural law, according to Hobbes, urges man to seek peace and follow it. Everyone has a duty to seek peace if there is a hope of achieving it. If this is not possible, then a person has the right to use any means that will give him an advantage in war (Hobbes, 1991, B. II: 98-99).

J. Locke, probably referring to Hobbes and his followers, criticizes those who equate the "law of nature" solely with concern for their own safety and well-being. Thus, in his work, which is an outline made before the writing of the "Second Treatise of Government", namely, in "Essays on the Law of Nature", Locke notes that in
Hobbesian solution, any ethical obligations imposed on man are reduced to utilitarian benefits. Thus, according to Locke, if the "law of nature" is understood as the methodology of selfpreservation, then any virtue will be correlated not so much with human duty but with human benefits, so only what may be considered useful will be deemed as moral. In such case, observance of natural laws will not be a moral obligation or an indisputable imperative, but will directly depend on profit (Locke, 2002: 110).

But for Locke, man is not only free and intelligent, but also morally oriented. And this position determines the specificity of Locke's understanding of the justice and essence of the social contract. For Locke, the essence of people is not reduced solely to a pragmatic interest, to satisfy which they are forced to form a system of state and legal institutions, and in the space of which it is only allegedly possible to talk about justice.

Both Hobbes and Locke tend to characterize people as independent, equal (from the beginning), and free individuals. However, Locke's understanding of initial equality and freedom differs from Hobbes's. After all, for the latter, most individuals are minimally rational (Kraus, 1993: 35-36). And if for Hobbes initial equality is only the cause of the "war of all against each other" and a precondition for a social contract, then for Locke initial (natural) equality is not the cause of conflict over resources, but the basis of reasonable peaceful coexistence between people: "... Because all people are equal and independent, none of them should harm the life, health, liberty, or property of another ..." (Locke, 1988: 265). Eventually, in the very fact of this equality lies the moral obligation of the individual to protect both his personal freedom and property (the latter is interpreted by Locke expanded), and the freedom and property of another.

According to Locke, man in his actions is guided not by fear, as Hobbes presents, but by rational imagination. In particular, "Essays on the Law of Nature" state that "... Not the fear of punishment, but a rational idea of what is right, binds us" (Locke, 2002: 118). It is about the inherent in the individual's ability to understand the natural law and the obligations of a moral and legal nature that flow from it. Moreover, these obligations, as Locke puts it, are the bonds of reason, which are universal in nature, because they are clear to all fully thinking subjects. Explaining his opinion, the philosopher notes: "If this law of nature is binding on at least a few people, it is obvious that 


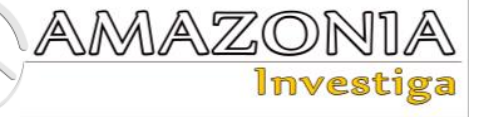

it must be equally binding on all, because the grounds for the obligation are the same for all people, as well as the identical way of human cognition and their very human nature" (Locke, 2002: 125).

It should be noted that the reconstruction of Locke's interpretation of the "law of nature", and the phenomena of freedom and justice, seems to be a rather difficult task. It is no coincidence that Locke's theory of the social contract is called "intolerable" by M. Nussbaum, because "... it contains heterogeneous elements that are extremely difficult to combine into a holistic picture" (Nussbaum, 2006: 41). And the point is not only that Locke's position changed somewhat during his lifetime, but also that such an important work in this context as the "Two Treatises of Government" was eventually composed of fragments written at different times and came to us in an unfinished form (in particular, the First Treatise). Later, Locke's liberal theory of justice, in terms of ethics, was somewhat supplemented by Rousseau and Kant (Rawls, 1999: 18).

In the fourth book of "An Essay concerning Human Understanding" (Locke, 1836), justice is investigated in close connection with sociopolitical practice, and Locke sees it as the purpose of ethics, which, in his opinion, is aimed at finding the rules of human action that lead to happiness. However, Locke's interpretation of justice differs from how Hobbes interprets it (although it is known that Locke's understanding of justice in general was formed under the influence of Hobbes' philosophy).

Locke's moral agreement between people precedes the socio-political agreement between them, and these agreements are based on universal rational principles, the most important of which are the principles of Justice and Freedom. This statement shows a fundamental difference in the views of Hobbes and Locke at the very moment of the "emergence" of justice.

Among other things, the human race is a specific community. According to Locke, this community could probably be enough for people to live, only if human depravity did not make living conditions in the "natural state" pretty unfit, and this fact forces them to create a state by treaty (Locke, 2003: 351). This position brings Locke closer to Hobbes, for whom the realization of justice is possible only after the conclusion of a social contract (formation of the state), which defines the principles of socio-political relations. And since the contract has been concluded all these relations occur between fellow citizens. By the way, the issue of justice is relevant not only for European culture. However, in other cultures, this issue has a different specificity. For example, in the realm of Sinitic civilization there are another approaches applicable to the interpretation of justice (Svyrydenko \& Stovpets, 2020; Stovpets, 2019; Stovpets, 2020: 63).

Hobbes's natural law presupposes the freedom of every man to use his own powers at his own discretion to save his own life and, consequently, the freedom to do all that, in his opinion, is most suitable for this purpose. And here Hobbes inevitably touches on the actual category of freedom.

The second natural law in Hobbes's concept presupposes the need for self-restraint. It is expressed in man's renunciation of the absolute right to all things (which one, according to Hobbes, was present in human beings in the "natural state") to the extent necessary in the interests of peace and self-defense. Thus the person should be satisfied with such degree of freedom in relation to other people, which he would allow for them in relation to himself, in case of the consent to these actions from others. Self-restraint is expressed in the refusal to prevent another person from benefiting from the right to a certain good. Here Hobbes speaks of the conciliation of interests: "The mutual transfer of law is what people call a contract" (Hobbes, 1991, B. II: 99-101). Hobbes' logic here is as follows: where there was no conclusion of a social contract, there no right was transferred; then each individual has an unlimited right to everything, and accordingly, no action can be considered unjust (because the criteria of justice have not been defined).

The third natural law is justice, which has a contractual basis and is conditioned by a previous agreement (Hobbes, 1991, B. II: 115). People must abide by the agreements they have made, otherwise they continue to be at war. If the contract is concluded, then its violation becomes an injustice. Instead, fulfilling the terms of a voluntary agreement is just and moral, because it meets the basic interests of human. Note that Hobbes continues to develop the idea of Aristotle, according to which the measure of justice is law, and the fulfillment of justice is possible only in the state, only where there is supreme power, and binding and obligatory laws (Aristotle, 1983: 376-380). Hobbes himself says in this regard that "... agreements without a sword are only words that cannot guarantee human security" (Hobbes, 1991, B. II: 129). 
It is known that Locke does not accept many provisions of Hobbes' philosophy. In his works there are direct attacks against Hobbes and his followers, which allows many to present these two philosophers as antagonists. The emphasis is usually on the fact that these two thinkers interpret the natural state differently, as well as goals, pursuing which individuals enter into a social contract. Finally, the different attitudes of these philosophers to authoritarian rule are emphasized. However, to talk about the diametric opposite of the two teachings is hardly possible.

In particular, reflecting on Locke's "Two Treatises of Government", P. Laslett notes: "... if Locke wrote his book as a refutation of Sir Robert Filmer, he could not have written it as a refutation of Thomas Hobbes ... It is a mistake to believe many in that Locke deliberately argues with 'Leviathan' in developing his theory of revolution" (Laslett, 2003: 67). Indeed, referring to the problem of freedom in the Second Treatise, Locke writes that 'freedom' is not what Filmer says: the freedom to do what you want and live as you please, without being bound by any law. Quite in the manner of Hobbes, Locke emphasizes that "... The freedom of people in the existence of a system of state power is to live according to a permanent law, universally binding on everyone in this society, and established by the legislative power formed within it" (Locke, 1988: 274-275). This example demonstrates the validity of Laslett's position that the contradictions between Locke and Hobbes are contradictions "within one party" (Laslett, 2003: 70), which was in the intellectual opposition to the ideologues of unlimited royal power, whose views were summarized by Filmer in "Patriarcha or the Natural Power of Kings" (Filmer, 2017).

However, unlike Hobbes, in whose political doctrine the problem of state power was key, Locke focuses mainly on the system of social relations. And even in the Second Treatise we can see that the theme of the state is secondary to Locke being at the background of freedom and law problems. While Hobbes describes the genesis of Leviathan's power, Locke turns to the understanding of the principles that determine the relationship between people, and he finds them in the "rationalized" natural law - in justice.

"Essays on the Law of Nature" states that justice is "the main law of nature and the connecting basis of any society" (Locke, 2002: 110). Like Hobbes, Locke links justice to the rule of law. However, unlike Hobbes, he does not interpret the rule of law principle as arising from the conclusion of a social contract. Locke's political anthropology differs significantly from Hobbes's, which explains his another understanding of the natural state, and his different view of the need for a social contract.

Locke demonstrates the close connection between equality, freedom and law. Equality of people by nature is not equality of talents or virtues, but the essence of "the equal right to natural freedom that everyone has", and, in turn, natural freedom is not to be bound by anything but the law of nature" (Locke, 1988: 292). Or, for example, he notes: "Man's freedom and freedom to act in accordance with his own will are based on the fact that man has a mind that is able to teach him the law by which he must govern himself" (Locke, 1988: 297). Locke distinguishes natural freedom from human freedom in society, and, as already noted, interprets freedom in the existence of a system of state power as a voluntary observance of socially established laws (guaranteed by the state). Thus, in contrast to Hobbes, Locke marks a fairly clear line between society and the state.

Locke's concept of justice is largely due to his ideas about the ethical unity of people. As per Locke, this unity is explained by the equality of all human beings, by virtue of belonging to the human race, and therefore, each individual is guided by a single natural law. At the same time, the ethical unity of people, in Locke's view, precedes their political unity. Unlike the materialist and pragmatist Hobbes, who rejected any transcendent foundations of human action, Locke prefers to emphasize human morality as a kind of motivating force.

This transcendent justification that Locke empowers with ethical and legal norms, plays an important role in his teaching, because, firstly, it provides some universalism and all-embracing nature of the "natural law", in oppose to the relativism of those laws that are established in the process of reconciling issues of public life. And, secondly, due to such a justification it becomes possible to talk about "pre-political" community of people (based on pre-conventional principles), which Locke calls the "natural state".

On the other hand, given that the "law of nature" is unifying for all human beings, Locke's natural and political states do not oppose each other as radically as Hobbes says. That is why the "natural state" is not considered by Locke as a state of lawlessness. As noted earlier, it is not a state in which the relationship between individuals can 


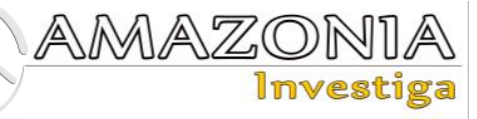

be freed from being guided by the principles of justice. After all, justice, as stated in the "Essay concerning Human Understanding", is "... a kind of treatment of the person or property of another, consistent with the law" (Locke, 1836: 376). The difference between political and "pre-political" communities is only in the presence or absence of institutionalized mechanisms for implementing the principles of justice. However, justice itself as an ethical category was outlined, according to Locke, in pre-state times.

Meanwhile, in the "political" state, justice is guaranteed by the legal system and the institutions of political and judicial power. Therefore, as it is reasonably stated, "... with becoming state-organized we have gained more justice, we have received better justice" (Harrison, 2003: 200), because here it is supported by a government established with civil consent.

For Locke, the close connection between justice and force (coercion) is also obvious. And in this idea, he is similar to Hobbes. In addition, Locke says about the rationality of the principle of justice: "... the criteria of 'just' and 'unjust' appear in our souls as the product of a developed mind and deep reflection" (Locke, 1988: 506). However, here he recognizes that not every individual is guided by reason in their actions. Passions are often stronger than reason. That is why in the natural state, where there are no institutions forcing individuals to abide by the rule of law, there are no guarantees for justice to be fully realized.

According to Locke, every individual has the natural ability to be a "judge" (i.e. to make judgments about what is fair and what is not, guided by the "law of nature"), but not everyone - for various reasons - can actually become a fair judge. Therefore, justice obviously needs more reliable and objective protection than the will and talents of individuals; and this is ensured only in the presence of the state.

The key to Locke's theory of justice is the concept of property. Thus, in "The Oxford handbook of British philosophy in the seventeenth century" (Anstey, 2013) there is a description of Locke's theory as a "propertybased theory of justice". And the preconditions for such a definition exist, because Locke himself states: "where there is no property, there is no injustice" (Locke, 1836: 422). And in "Thoughts on Education" Locke writes that "teaching justice" is an important stage of education, which begins with the formation of children's understanding of what property is (Locke, 1988: 506). Locke's maxim about the connection between justice and property needs to be explained. As we noted earlier, the thinker interprets property in an expanded way.

Under property, Locke understands not only the property belonging to man (estate), but along with it, "property" includes both human life and freedom. Protection of property (in its expanded sense) is the main goal of a justly organized society. In other words, Locke defines the task of the political community neither to ensure full estate equality, nor even to distribute benefits fairly (although this is important), but to create conditions for the individuals to use their property in different ways (Locke, 2003: 350). That means real opportunities to fulfill various interests of life, but taking into account the similar interests of others in society.

Here we have to put a conditional point in our study of the phenomena of Freedom and Justice in the interpretations of Thomas Hobbes and John Locke. Of course, this issue seems hardly to be considered exhausted.

\section{Conclusions}

Summarizing the study, we note that we made an attempt at a historical and philosophical representation of T. Hobbes's and J. Locke's visions on the essence of the phenomena of freedom and justice. This analysis made it possible to identify the fundamental ideological conflict between statism and liberalism, between the utilitarian, entirely pragmatic understanding the nature of the social contract (in Hobbes' political philosophy), and the moral and ethical emphasis on the essential foundations of stateorganized society (in Locke's philosophical visions).

Unlike Hobbes, whose doctrine of freedom and justice developed as a concept of realization of the person's particular interest, Locke focused on the common wealth, i.e. the public good. It is the criterion of legitimacy and justice when it comes to the need to use force by the political and judicial power of the state. At the same time, any actions of the authorities not aimed at achieving this good are considered as violating the agreement concluded between fellow citizens.

Locke insists that the common good presupposes the preservation of each individual's identity, which is realized through guarantees of freedom, the right to fair treatment, and respect for personal and property rights. All the mentioned 
in its complex becomes the main goal of a politically organized community, and constitutes the content of a social agreement, acting as a guarantee of social solidarity and unity in equal opportunities. Besides that, as follows from Locke's works, full-fledged social integration is possible only under conditions of observance of the principles of justice. It becomes the main law of nature of any society. However, the specificity here is expressed in the fact that Locke connects justice with ensuring equality in the fulfillment of individual rights.

Hobbes, without denying the above principles (however, most clearly articulated by Locke), emphasizes the key role of the state in consolidating free and selfish individuals into a single political community, within which there is such an emergent quality as "justice". The freedom of the individual loses its absolute character, as each member of this socio-political community gives up a part of his freedom in favor of 'Leviathan' (i.e. the sovereign, the state), agreeing to limit his freedom (which derives from "natural law" in Hobbes' sense) in exchange for welfare and relative security. Beginning from this moment it is fair for each individual to comply with the terms of that universally binding social contract, and injustice is to violate it accordingly by someone within the community.

We guess, in Hobbes's political conception, a strong point is its realistic and pragmatic nature, in particular that Hobbes takes into account a marginal element - the reluctance of individual members of the community to self-restraint other than under pressure from society and the state. At the same time, Hobbes generally ignores the moral and ethical preconditions inherent to human nature, reducing the ontology of the social contract to purely utilitarian aspects. In addition, Hobbes's philosophy somehow ignores the problem of the possible usurpation of power by the sovereign himself, when this Leviathan becomes a totalitarian being, which itself violates social agreement, devaluing the interests of the whole community and each of the individuals. Then justice is obviously lost.

Locke, on the other hand, forms an idea of the ethical and legal community of people, which, as its guarantee, needs institutions of political and judicial power based on the principles of justice. But fundamentally important, in the context of our study, is that Locke's political anthropology is based on the close relationship between the principles of justice and the imperatives of reason. The latter are not identified by Locke solely with the rational calculation of individual interest, but approach the universal ethical and legal requirements to ensure equal opportunities in the implementation and protection of freedoms and interests of the individual living in society. Justice, under such conditions, means that a person acquires the maximum opportunities to unfold his own freedom (in all its diversity), without violating the freedoms of others.

\section{Bibliographic references}

Anstey, P.R. (2013). The Oxford handbook of British philosophy in the seventeenth century. Oxford: Oxford University Press.

Apeldoorn, L. (2020). On the person and office of the sovereign in Hobbes' Leviathan. British Journal for the History of Philosophy, 28(1), 4968.

https://doi.org/10.1080/09608788.2019.1613632 Aristotle. (1983). Works: in four volumes. Vol. 4. Translated and edited by A.I. Dovatur. Moscow: Mysl.

Bruner, J.P. (2020). Locke, Nozick and the state of nature. Philosophical Studies, 177, 705-726. https://doi.org/10.1007/s11098-018-1201-9

Connolly, P.J. (2019). Locke's Theory of Demonstration and Demonstrative Morality. Philosophy and Phenomenological Research, 98(2), 435-451. https://doi.org/10.1111/phpr.12512

Davis, M. (2012). Locke on Consent: The 'Two Treatises' as Practical Ethics. The Philosophical Quarterly, 62(248), 464-485. https://doi.org/10.1111/j.1467-

9213.2012.00045.x

Day, J.P. (1966). Locke on Property. The Philosophical Quarterly, 16(64), 207-220. https://doi.org/10.2307/2218464

Fleming, S. (2020). A Political Theory of Treaty Repudiation. The Journal of Political Philosophy, 28(1), 3-26. https://doi.org/10.1111/jopp.12195

Filmer, R. (2017). Patriarcha, or the Natural Power of King; and Other Political Works. Ed. by P. Laslett. London: Taylor and Francis.

Hardin, R. (1993). From Power to Order, From Hobbes to Hume. Journal of Political Philosophy, 1(1), 69-81. https://doi.org/10.1111/j.1467-

9760.1993.tb00004.x

Harrison, R. (2003). Hobbes, Locke, and confusion's masterpiece. An Examination of Seventeenth-Century Political Philosophy. Cambridge: Cambridge University Press.

Hobbes, T. (1991). Works: in two volumes. Vol. 1, 1989. Vol. 2, 1991. Moscow: Mysl.

Hobbes, T. (2010). Leviathan: Or the Matter, Forme, and Power of a Common-Wealth 


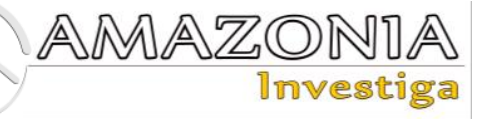

Ecclesiasticall and Civill. Ed. by Ian Shapiro. New Haven: Yale University Press.

Hoye, M.J. (2019). Natural Justice, Law, and Virtue in Hobbes's Leviathan. Hobbes Studies, 32(2), 179-208. https://doi.org/10.1163/18750257-03202004 Kraus, J.S. (1993). The Limits of Hobbesian Contractarianism. Cambridge: Cambridge University Press.

Laslett, P. (1956). The English Revolution and Locke's "Two Treatises of Government". Cambridge Historical Journal, 12(1), 40-55. https://doi.org/10.1017/S1474691300000329

Laslett, P. (2003). Introduction to Locke's Two Treatises of Government. Cambridge: Cambridge University Press.

Locke, J. (1836). An Essay Concerning Human Understanding. London: T. Tegg and Son.

Locke, J. (1988). Works: in three volumes. Vol. 3. Moscow: Mysl.

Locke, J. (2002). Essays on the Law of Nature. Locke J. Political Essays. Ed. by M. Goldie. Cambridge: Cambridge University Press.

Locke, J. (2003). Two Treatises of Government. Ed. by P. Laslett. Cambridge: Cambridge University Press.

Miller, D. (2011). Property and Territory: Locke, Kant, and Steiner. Journal of Political Philosophy, 19(1), 90-109. https://doi.org/10.1111/j.1467-

9760.2010.00377.x

Moehler, M. (2019). Diversity, stability, and social contract theory. Philosophical Studies, 176 , 3285-3301. https://doi.org/10.1007/s11098-018-1174-8

Nussbaum, M.C. (2006). Frontiers of Justice. Disability, Nationality, Species Membership. Cambridge, MA: The Belknap Press of Harvard University Press.

Olsthoorn, J. (2013). Hobbes's Account of Distributive Justice as Equity. British Journal for the History of Philosophy, 21(1), 13-33. https://doi.org/10.1080/09608788.2012.689749 Platón. (1962). The Statesman. Republic. Laws. Transl. and ed. by W.R.M. Lamb, H.N. Fowler. London: William Heinemann, 449 pages.

Rawls, J. (1999). Theory of Justice. Cambridge, MA: The Belknap Press of Harvard University Press.

Seagrave, A.S. (2015). Locke on the Law of Nature and Natural Rights. Chapter 19 in "A Companion to Locke" by Matthew Stuart. Hoboken: John Wiley \& Sons, Inc., 584 pages. P. 371-393.

https://doi.org/10.1002/9781118328705.ch19

Skinner, Q. (1999). Hobbes and the Purely Artificial Person of the State. Journal of Political Philosophy, 7(1), 1-29. https://doi.org/10.1111/1467-9760.00063

Springborg, P. (2016). Hobbes's materialism and Epicurean mechanism. British Journal for the History of Philosophy, 24(5), 814-835. https://doi.org/10.1080/09608788.2016.1212699 Svyrydenko, D., \& Stovpets, O. (2020). Chinese Perspectives in the "Space Race" through the Prism of Global Scientific and Technological Leadership. Philosophy and Cosmology, 25, pp. 57-68. https://doi.org/10.29202/phil$\operatorname{cosm} / 25 / 5$

Stovpets, O. (2019). Chinese legal-philosophic syncretism and its influence to value orientations of the Chinese society. Skhid, 1(159), pp. 55-60. https://doi.org/10.21847/1728-

9343.2019.1(159).157856

Stovpets, O. (2020). Sinitic civilization's worldview features and their system-forming role in the complex of social relations in modern China. Interdisciplinary Studies of Complex Systems, 17, pp. 59-72. https://doi.org/10.31392/iscs.2020.17.059 